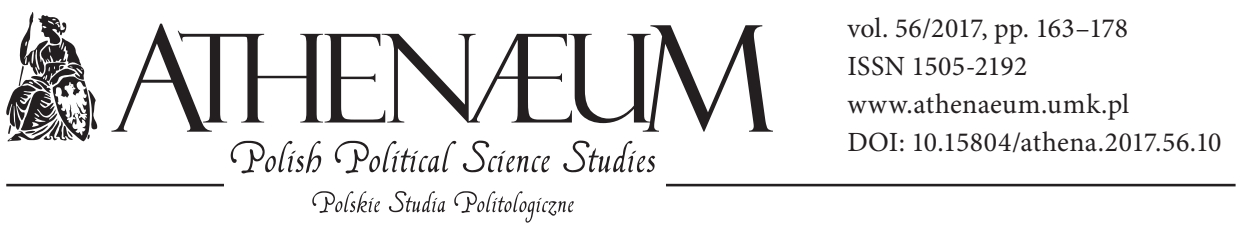

\title{
RUSSIAN PHOBIA OR A REAL THREAT? PROPAGANDA-RELATED ELEMENTS OF RUSSIAN INFORMATION WARFARE IN UKRAINE AND THEIR IMPLICATIONS FOR EURO-ATLANTIC SECURITY*
}

\author{
ROSYJSKA FOBIA CZY RZECZYWISTE ZAGROŻENIE? \\ ELEMENTY PROPAGANDOWE ROSYJSKIEJ WOJNY \\ INFORMACYJNEJ NA UKRAINIE I ICH IMPLIKACJE \\ DLA BEZPIECZEŃSTWA EUROATLANTYCKIEGO
}

Anna Antczak**

\begin{abstract}
The article discusses Russian information warfare focusing mainly on propaganda issues, which were used during the conflict in Ukraine, and tries to find an answer to the question of to what extent these undertakings are dangerous to Euro-Atlantic security. It provides a political background of the conflict in order to better understand why Russia is using particular information warfare tools. The article analyzes manipulation techniques and the use of specific elements of Russian identity such as the attitude to history and the role of the Orthodox Church. Finally, it discusses a possible influence these actions may have on security and stability of
\end{abstract}

Artykuł dotyczy wojny informacyjnej prowadzonej przez Federację Rosyjską i koncentruje się głównie na kwestiach związanych z narzędziami propagandowymi, które były wykorzystywane podczas konfliktu na Ukrainie. Artykuł stanowi także próbę znalezienia odpowiedzi na pytanie, do jakiego stopnia rosyjskie działania są groźne dla bezpieczeństwa euroatlantyckiego. Kwestie te są zaprezentowane na tle politycznych realiów konfliktu, aby lepiej zrozumieć, dlaczego Rosja wykorzystuje konkretne narzędzia walki informacyjnej. Artykuł analizuje techniki manipulacji, w tym stosowania specyficznych elementów tożsamości rosyjskiej, takich jak historia czy Kościół

* The research leading to these results was conducted within the Eisenhower Fellowship granted by the NATO Defense College in Rome.

** Academy of Finance and Business Vistula in Warsaw, Department of Business and International Relations. 
the EU and NATO and their particular member states.

Keywords: information warfare, Russia, Ukraine, propaganda, security prawosławny. Artykuł zamyka analiza możliwego wpływu tych działań na bezpieczeństwo i stabilność UE i NATO oraz poszczególnych państw członkowskich.

Słowa kluczowe: wojna informacyjna, Rosja, Ukraina, propaganda, bezpieczeństwo

\section{INTRODUCTION}

"After the latest wave of collective ecstasy, the morning-after letdown came" that is the way Alvin and Heidi Toffler (1994) comment on a common conviction that we are living in an era of peace, in a world free from world wars, especially the ones including world great powers. The example of Ukraine shows that war can take place in Europe at NATO's borders and be provoked by a great power which finally even took part in it. Now, the main question is whether the RussiaUkraine conflict may have long-lasting significant consequences with respect to the European order and security, which could bring serious implications for the Euro-Atlantic security. Thus, the main aim of this paper is to identify the drivers for the possible escalation of the conflict and their implications for Euro-Atlantic security with the greatest attention given to propaganda-related issues. Hence, the main question to be answered is: to what extent can Russian information warfare tools based on propaganda be perceived as a real threat to European security? It is not the aim to evaluate Russian proceedings with respect to ethical issues or to claim that what they do is unprecedented. It is just about showing how this process functions. This article, examining current literature on Russian propaganda (with the main focus on the research conducted by P. Karber, M.H. Van Herpen and J. Darczewska), contributes to the debate on Russian information warfare, providing deeper insight into strategies, methods and tools used as well as the reasons of their employment. The article begins with concise insight into the conflict. The main part is devoted to the analysis of Russian propaganda and information warfare, and its influence on Euro-Atlantic security. 


\section{POLITICO-STRATEGIC BACKGROUND OF THE CONFLICT}

A short analysis of strategic movements of the Russian Federation will be a starting point for further considerations. Moscow's neo-imperial approaches were started by the coming into power of Vladimir Putin, who claimed that the collapse of the Soviet Union was the greatest geopolitical catastrophe of the $20^{\text {th }}$ century. Thus, all his actions have been directed at regaining hegemony in the region and subordinating or at least having the power of influencing strongly the former Soviet republics. To achieve this, a project of "New Generation War" was created. It combines low-end (including hidden state involvement) and highend direct superpower actions (Karber, 2015). This strategy was first tested in Chechnya and Georgia, then improved and again tested in Ukraine in order to improve it even more. Russian idea of a new generation warfare is based on five main elements (Karber, 2015): political subversion (mostly propaganda), proxy sanctuary (taking over local political centers and training of guerrilla fighters), intervention (sudden deployment of troops near the border), coercive deterrence (dislocation of tactical nuclear delivery systems and accompanying manoeuvers), and negotiated manipulation (abuse of the negotiated ceasefires).

There are also quite a few internal factors which facilitated the conflict to emerge. As there have been many publications on that topic issued so far, just to mention them: clashes between aspirations of the pro-Western part of the Ukrainian society and the decisions of president Yanukovych; social stratification - the issues of ethnicity, political beliefs and wealth; oligarchy; corruption; uneven distribution of resources; poverty of the society; deep divisions according to the future political path (the EU versus Russia); weak "offer" of the EU and NATO towards Ukraine; energy dependency, lack of common European energy market; weakness of the state in economic terms; clash between the state integrity and the idea of self-determination of nations; particular vulnerability to separatist forces due to regional diversity; high decentralization of the country; multi-ethnicity and strong Russian minority. As far as Russia is concerned, its foreign policy is consistent with the traditional aspiration - to establish an informal empire in the post-Soviet area. It is also worth remembering that almost every Russian regional project in Eurasia has first been introduced, tested, and applied to two states - Belarus and Ukraine. While the 2004 Orange Revolution in Ukraine discredited Russia's hopes of including Ukraine in a super-national body, Moscow at least maneuvered to ensure that Ukraine would not join NATO. By fostering internal turmoil in Ukraine, Russia chose not to assume direct 
control over Ukraine, but instead to promote and support its protégé, Viktor Yanukovych, to the highest political post. Russia assertively declared its intention to protect its geopolitical and economic interests in the international arena and in its immediate neighborhood, while liberal technocrats were against restoring Russia's direct rule over other members of the CIS (because of Russia's economy and budget). Nevertheless, a good idea was to split Ukraine into smaller pieces, which started to be realized using the "New Generation War" doctrine, which clearly stated that NATO expansion was one of the greatest external threats as well as that Russia had the right to intervene in its closest neighborhood including military intervention whenever neighboring countries' governments would not realize Russia-friendly politics (in line with Moscow's interests).

The emergence of the crisis in Ukraine forces reflection on the character of engagement in the conflict - if it is new warfare and if so, what are its most important characteristics? "New" war does not necessarily have to mean direct engagement of military force. Non-military means are often used in asymmetric conflicts against weak or failed states (because of their fragile institutional and governance system, social stratification, feeble armed forces, unstable political system, etc. - Russia benefited from all these factors in Ukraine). Different from a traditional way of subordinating territories by third parties or non-state actors was reflected in the actions undertaken by separatist groups composed of national, ethnic or religious minorities. They became a new and powerful weapon, and their claims - at least outwardly - hard to be questioned (i.e., the self-determination of nations fight, even though it is incorrectly perceived in this case). Separatism allows targeting dissatisfaction of the society with the current situation in such a way that compromise seems virtually impossible, as there are no common points to build consensus on. If national minority feels (or is inspired to do so) that the rights are not respected, it starts to seek for alternative solutions being hard to argue with and becomes propaganda susceptible.

\section{SPECIFIC INSTRUMENTS OF RUSSIAN INFORMATION WARFARE}

Events in Ukraine clearly show the extent to which new technology can be incorporated into policy and information warfare. Very well organized Russian propaganda has played a huge role in the war, presenting in the media the members of the interim government in Kiev and their followers as fascists who brought Ukraine to the brink of a civil war. The message concentrated 
mainly on emphasizing the illegitimacy of the Kiev government which takes unlawful actions against the separatists. This message was copied by a large part of the Western media, while Russian society was permanently misinformed and manipulated by government propaganda. The other important tool used is social media, giving the possibility to publish in real time, provide enormous power to anyone who uses these tools. Many young people are susceptible to the influence of these media (the ease of recruiting very young people to extremist groups). It is instantaneous communication which is going to be the most serious challenge for the armed forces in the area of information and psychological operations. Maintaining secrecy necessary to conduct a particular type of military action will become more difficult, because it may happen that the media will tend to outstrip military operations. Thus, they will become a more and more important participant of war affecting it directly, or even controlling it (deliberately or indirectly and unconsciously).

Russian propaganda often uses the motif of brutality of the proceedings of the opposing party (particularly desirable are images showing violence against women and children). Suffering of civilians (mostly children) during the armed conflict has become the primary weapon used by information warfare. Information and psychological operations are addressed in at least two ways - international community (in this case, suffering of the civilian population motif is most often used), and the local population (in this case propaganda can take many forms, depending on the effect that is intended to be achieved - to win favor, the conviction of the rightness of actions taken, the infallibility of authority, gaining support for authority, blind obedience, etc. $\left.{ }^{1}\right)$. Nationalism and xenophobia are widely propagated in order to unite "indigenous Russian population". All actions taken by the authorities are supposed to bring about confusion and capturing the public into the trap of fears, phobias and anxiety (Van Herpen, 2015). "The regime deliberately tries to keep the minds of the society in a state of schizophrenia, so as to hinder the formation of civic culture and legalistic mentality" (Shevtsova, 2007).

Putin's propaganda however has created a sense of danger and a non-existent image of the conflict. Not only has the West partly believed in it, but also has not found any answers yet. The way to fight against Russian propaganda, which should be a strategic priority especially for the Baltic countries, Ukraine, Georgia

1 In this case, propaganda offers crafted manipulated messages which are using the mixture of false or incomplete data and generally known facts or information. 
and Moldova, must be the development (or empowerment) of comprehensive national strategies aimed at the media and strategic communication at the intergovernmental level, which should be consistent with policies of other countries (Lange-Ionatamišvili, Potjomkina, 2014). Information warfare is intended to have power over public opinion in order to serve the objective of the government, however in the twenty-first century, in the era of the knowledge society, it is a difficult task. Russia's imperial ambitions may be nineteenth century in nature, but what matters in the twenty-first century is the audience, and most importantly, the performance. In case of Russia, each message is carefully tailored for a concrete recipient. Russian success in the information war illustrates how concepts such as war, occupation, and intervention can be dismissed from their previous points of reference.

Putin's stimulus for propaganda arises from the ideology of two people: Igor Panarin (a professor at the Diplomatic Academy of the Ministry of Foreign Affairs and a former KGB agent) and Alexander Dugin (inspirator of the Eurasian Union project). While Panarin considers the collapse of the Soviet Union as a result of the United States' and Great Britain's "First Global Information War" (Van Herpen, 2015) against the Soviet Union, Dugin stands in favor of "magical and mystical theories, mixed with fascist-oid, neo-imperialist geopolitical ideas" (Van Herpen, 2015). Russian propaganda is one of the most important tools of the "soft power", which in fact is redefined by Russia into "hard power in a velvet glove" (Van Herpen, 2015). First of all, it is reduced strictly to public diplomacy (no civil society involvement) - which means mainly manipulation and disinformation. In this way, soft power tools began to be perceived as a part of a zero-sum game with a state being the only winner (like in the case of hard power). Finally, Russian soft power uses also illegal tools like bribery, illegal funding of politicians and political parties, corruption and espionage. This in turn means focusing on three main components of Russian soft power, which is very often reduced to a very broad information warfare and propaganda: "mimesis", "rollback" and "invention" supported by other activities. As Van Herpen (2015) explains, “"Mimesis» consists of attempts to copy Western public diplomacy, «rollback» is a strategy of attacking Western public diplomacy initiatives, and «invention» includes new methods of information warfare" which are not necessary that innovative, as they originate from the Soviet KGB practices. These activities are strongly supported by the Russian Orthodox Church as a defender of traditional values, which is the Kremlin's tool to propagate messianic ideology, glorifying the state and being deeply nationalist, homophobic 
and denying Western values being also supported by Russia's narrative based on historical memory.

Russian perfectly tailored propaganda (using half-truths and truths out of context) is focused on three dimensions: own society, the closest neighborhood, and the rest of the world. In the first case, Russia is aimed at gaining social support for its activities and evoking a sense of injustice, alienation and unfair rejection by the rest of the world, but mainly by the Western society. In such an atmosphere, the society feels exceptional and praises activities carried out by the state (reconstruction of Russian superpower) on the one hand, but on the other, it feels unreasonably alienated, which deepens the antagonism between the values of the East and the West. This makes it easier to manipulate the society, which is then more eager to bear the inconvenience of running the armed conflict (e.g., food shortages due to Western sanctions or reductions in social spending and wages) longer and more generously. Propaganda directed at the nearest neighbors is a warning intended to arouse fear and concern in countries that they can meet a similar fate. In this way, Russia may try to force subordination (e.g., the Caucasus, Georgia, Moldova, Belarus) or pursue other political objectives (in the case of the Baltic states, Scandinavia and Poland), while in relation to Ukraine Russia conducts deprecation policy. International propaganda is supposed to introduce continuous disinformation, confusion, manipulation and is an attempt to create permanent divisions among Western countries. Russian propaganda and provocation, which takes quite central stage, created a sense of danger and stopped the West to act more actively. Escalating internal and external propaganda, Russia spreads out anti-West moods and looks how far it may reach. Russia also benefits from the West's inability to act united, its organizations' bureaucracy and "political correctness", while Russian political declarations are unequivocal with respect to their actions (not only in relation to Crimea and eastern Ukraine, but also to refugees' issue, Syria conflict, ceasefires, etc.).

It is worth noting that Russian media coverage contradicts itself - it provides contradictory information to excite doubts in Western society about its fundamental principles and values. This is also aimed at undermining the authority of journalism, discouraging people from relying on the media coverage and introducing chaos by administering multiple versions of events instead. "Russia Today" - the second largest station broadcasting in English - invites a few "experts", each of them presenting a different point of view followed by a discussion which is to cause chaos in the mind of the recipient. One should realize 
that Russian propaganda is not really directed at Ukraine, but at the Western world. The point is that Western societies behave in accordance with the will of the Russian President. It is all about diffusion of their faith and unity, to loosen the ties between the NATO and EU member states. United West poses a serious challenge for Russia, but West divided and weak does not any more. Then, the way to restore the Russian empire is open. Russian propaganda experts are much more familiar with the Western system of values and mechanisms of perception with the way of understanding events than Western societies understand the mentality of societies ruled in an authoritarian manner for centuries.

Russia's phenomenon is that it weaponizes absurdity and unreality to disrupt Western narratives, the concept of truth is no longer relevant. On Russian TV news broadcasts, the borders between fact and fiction are blurred and the newly invented concept of Novorossiya is a sign of the national manipulation system being globalized (Pomerantsev, 2014). While the Kremlin intensifies its propaganda activities, the West undergoes its own crisis with respect to the idea of truth. Russia in its media coverage tries not so much to convince, but rather leave the audience confused and passive. These actions are aimed at disrupting the Western narratives, with the central idea of "if nothing is true, anything is possible", which evokes the feeling of unpredictability or even threat (Pomerantsev, 2014).

Societies with centralized media dependent on authorities to a large extent are easier to be manipulated. They have been subjected to the same propaganda for years aimed at forcing worship for authority and its decisions, full identification with its objectives, as well as the ability for significant sacrifices for the "higher necessity" associated with the government. Most of the society does not perceive information they get to be a manipulated product of the governing elites. On the other hand, this society needs some kind of illusion to be able to survive while living in poverty, with no prospects for a change. Thus, the promise that at least the country will become "great and powerful" keeps them in the belief that they are better than others, and their behavior is right. While media propaganda practices seem to be obvious for postmodern societies, for others they are a source of worship and hope. For these reasons, postmodern societies prefer the message to be more personal and interactive (social media), thus perceived as more reliable. That is the type of tools which were used by the Ukrainian society during the protests on Kiev's Maidan. Currently, the aim is to individualize the message and show particular tragedies which are more persuasive and social media are a good tool for such kind of actions. Media also play a significant role 
in the process of dehumanization of the adversary whose image is created in an extremely unfavorable way (highlights the "inhuman" features by focusing on the appropriate behaviors, actions, etc.) in order to achieve public support for the use of force against him.

Successfully conducted propaganda campaigns can have a significant and long-lasting impact on behavior, opinions, views, and even values presented by the whole society. A good example is the activity carried out by Russian government towards its own population in order to spread out disinformation and manipulate social moods. The Kremlin, controlling media coverage, has achieved one of the main objectives of its information warfare in an unprecedented way, namely Russians' negative perception of Ukraine (64\%), the EU (71\%) and the USA (81\%) together with the societies of these countries (Prus, Secrieru, 2015). Information warfare, considered by Russia as one of the elements of the hybrid warfare, focused mainly on mass manipulation through the media, including social networking and fueling public sentiment, which is based on imperial resentment as well as a sense of injustice and mistreatment of Russia and its citizens by the West. No alternatives are allowed, and support for aggressive actions in Ukraine is won by persuading the society that national pride, Russia's appropriate place in world politics and respect can be gained only by strengthening the power and expanding the zone of Russian influence. This message is tailored to suit the society's sentiments, especially if it is devoid of any "audible" alternatives even in the social media. The Kremlin hires the so-called trolls ${ }^{2}$ producing favorable content and placing it in social networks (Darczewska, 2014).

The main tools that are used may be covert or overt and these are: propaganda (white, gray and black); intelligence; analytical component dealing with media monitoring and the analysis of the current situation; the organizational component (primarily used to influence the media) as well as special forces operations, including sabotage (Darczewska, 2014). The very process of managing information operations is divided into five stages: forecasting and planning, organization and stimulation, feedback, operations' correction and control of the implementation (Darczewska, 2014).

With regard to the Russian TV propaganda directed at the conflict with Ukraine, there are used the same techniques aimed at discrediting Ukraine as a state and undermining its credibility by ridiculing its political leaders and

\footnotetext{
2 To be discussed later.
} 
society by accusing of fascist inclinations. The West is perceived as being passive on the one hand and possessing a hostile attitude to Russia on the other. Ukraine is presented as an aggressor and oppressor of the Russian minority, while the separatists as protectors of the civilian population living in eastern Ukraine. This is the setting in which Vladimir Putin presents himself as a hero and a courageous leader ready to face the whole world (if forced to do so) to defend his citizens and the values they believe in.

All Russian propaganda activities are in line with the basic rules of its successful application (Darczewska, 2014):

- the principle of mass and long-term operation (using multiple stereotypes, i.e.: "the orange plague" or "the Bandera (Nazis)");

- the principle of desired information (relating mainly to the basic concerns and/or expectations of Russians and Russian-speaking population, e.g., to protect their rights and, therefore, the manipulated information about them been broken by the alleged ban on the use of the Russian language, would definitely not fall on deaf ears);

- the principle of emotional stimulation (evoking an appropriate emotional state in order to stimulate activity for emotional rather than rational reasons);

- the principle of intelligibility (simplified, "black and white" messages not allowing for own assessment, which is delivered directly through the keywords, e.g., Russophobia, spy, traitor, agent, etc.);

- the principle of an alleged obviousness (evoking associations between propaganda statements and created political myths, e.g., Russian spring - patriotism; Bandera - fascism; Maidan - chaos, Chechnya - terrorism, the West - liberalism and aggression; Ukrainians - radicals, nationalists, aggressors, "Ukrofacists" and anti-Semites, the USA - the enemy, etc.).

Moreover, manipulation with the image on Russian television is a commonplace. The same pictures serve as material illustrating and telling completely different stories. With all this, it is worth remembering that for most Russians, television is the main source of information and according to various polls, a large number of them believes that this message is true and objective.

Russian authorities can easily introduce propaganda messages to social circuit, because most of the media remain under the state control and influence. Thus, all news distributed is subordinated to the information strategy, even if the message seems to be chaotic and inconsistent at first glance. It just means that it has a specific task to fulfill (evoking chaos and causing irritation among the recipients), as it 
was the case of the information about the shooting down of the Malaysian aircraft over Ukraine. It is also common to use the same image in completely different contexts in different TV stations. It is somewhat more difficult to control the Internet coverage, and therefore there were formed special teams to disseminate propaganda messages within the network. These are organized activities aimed at conducting information warfare through techniques available on the Internet, including the famous Russian trolling ${ }^{3}$. Of course, in terms of the tools used, the Internet warfare is no different from the one carried out in the traditional media. The biggest field of possibilities for the spread out of propaganda in Russia is television, because, as mentioned before, the vast majority of Russians receive all the information and "knowledge of the world" from there.

Russian propaganda uses mainly the technique of disinformation not even in order to influence the society's perception of reality, but to create a completely new reality. It is mainly about creating the message so as it includes the following elements: the truth, something that society would like to be true, and the falsehood. A perfect example could be the message concerning the annexation of Crimea. The first element (truth): historically, Crimea had been more strongly associated with Russia than with Ukraine for a long time. The second component (the wishful thinking): Crimea is as "Russian" as Tula or St. Petersburg. The third element (falsehood): ethnic Russians in Crimea were haunted by the Ukrainian authorities and needed Russia's support. Russian propaganda also relies heavily on stereotypes built on the canvas of the established historical memory and myth, historical and cultural heritage and the need to defend the values of the Orthodox Church with the consequent conviction of the spiritual uniqueness of Russia and its society. Such propaganda makes the audience believe in the content of messages without reflection, unquestionably and permanently. Most Russians are subjected (vulnerable) to the Kremlin's propaganda mainly because it is easier for them to some extent - it is better to believe than to fight it, especially as it is effective while touching sensitive issues within the nation.

It is also necessary to mention that propaganda is present not only in Russian media, but is also targeted at the youngest audiences through other channels. It is manifested by an obligation to use the "standardized" textbooks (especially in

3 Trolling aims at carrying out malicious actions in social media, posting information subordinated to one idea, which is not (or does not have to be) consistent with the reality, regardless of their ethical or moral consequences. Trolling is to introduce confusion (e.g., to undermine credibility, etc.) or manipulation within the particular audience the message is directed at. 
history) or teaching of Russian alphabet in accordance to "political correctness" (e.g., the letter "a" stands for "antiMaidan", "d" for "Donetsk", "p" for "Putin") being accompanied with properly chosen "patriotic" illustrations. It is also worth mentioning that Russian patriotism is far from promoting the idea of pacifism and peace. On the contrary - from an early age Russians are brought up in the spirit of struggle and the need to stand up for their homeland, whenever it is "threatened" (the case of Crimea and eastern Ukraine as well as previously Georgia - it was in line with the propaganda message of the Kremlin).

The last crucial element of Russian propaganda is the image of the leader. The cult of Vladimir Putin as a strong, courageous, athletic, trustworthy, beloved by the people hero is a very important part of the indoctrination activities, which are used on a daily basis. They get intensified during the pre-election period and take diverse form depending on to which segment of audience they are directed at (the macho image, trustworthy statesman, a powerful governor, a leader sensitive to the plight of his society, etc.).

Russian propaganda is based largely on the use of history, which becomes both the weapon of information warfare and political discourse. Manipulation of facts on the one hand serves the unification of Russian society, on the other it is an excellent tool for introducing the message based on the binary oppositions technique because it supports the policy of confrontation as well as reluctance of Russian society towards Western societies. The Second World War and the victory over Nazi Germany became the object of mythologization, and for the Kremlin - a source of legitimacy for all the activities currently being undertaken, both in domestic (such as civil rights and liberties restriction) and foreign policy (e.g., actions against Chechnya, Georgia and Ukraine). The Second World War, called the Great Patriotic War by Russians, became the basis for the justification of any state's action "against the resurgence of Nazism and fascism", no matter what kind of action it would be. Glorification of war and its misrepresentation comes down to believing that the victory over Germany meant also the victory over the West in the sense that the Soviet Union managed to achieve the unreachable. Consequently, there arouses the belief that "we can beat anyone", with the very victory being attributed more to a country as such rather than the people. For this reason, today it is easier for Russian authorities to achieve subordination and agreement for certain actions (successful state, which has the right to undertake internal and external activities in order to pursue with similar great deeds). Significantly, the Great Patriotic War is presented as being purely defensive and as such it provides a historical basis for justifying further 
"exclusively defensive" Russian actions (in Chechnya, Georgia, Ukraine, but also Syria and to some extent Turkey). Every action is justified by the necessity to defend (the population, values, culture, faith, sovereignty, etc.). With the same reasons Russian society is ready to bear some consequences and tolerate the negative effects of the actions taken by the Kremlin. The struggle against the neo-Nazi fascist forces in Ukraine has become a leitmotif to justify Russian aggressive actions in Ukraine (Prus, 2015). Hypocrisy of this type of rhetoric is all the greater, the more openly Russia cooperates with ultra-nationalist and neo-Nazi political parties and organizations in Europe at the same time in order to influence the European Union countries (support for the Euro-sceptical movements which aim at the dissolution of the EU). Mythologizing and glorifying the Great Patriotic War rhetoric also served as a support to justify the annexation of Crimea (a site of military glory and victories of the Soviet Union during the war). These instruments of misinterpretation of history also cause deepening of hostile confrontation between Russian society and the West.

\section{CONCLUSIONS}

The above analysis implies that Russia, as any other country tending to restore its power (in case of Russia - its former imperium), is using various tools to build its strategic position, which should not be surprising nor demonized. It should be just appropriately approached. Current situation in Ukraine strengthened Russian strategic position with respect to both - the EU and NATO, thus some of the European countries may feel threatened (especially the countries of Central and Eastern Europe to whom Russia is an "eternal enemy"). Western societies tend to be very vulnerable to propaganda (not only Russian, but also the one of Ukraine and Eastern European countries). Each of these countries has its own interests and wants to convey its message. In order not to get caught into the Russian propaganda ambush, nor to be pressured by Eastern European hysteric phobia or to be manipulated by Ukrainian self-interests of an "unsolicited child", there is a need to determine real threats out of the possible challenges as objectively as possible. The fact is undoubtedly that Russian challenge brings about new threats to European security, especially for Eastern European countries. The greatest seems to be the new role of national minorities, as Russia uses minorities' manipulations for political reason very skillfully, having spectacular successes in Ukraine, Georgia and Chechnya on this ground. 
Russian propaganda is not a new threat, but still not properly approached. There is a need to conduct an in-depth analysis of this phenomenon in order to take appropriate measures. Russian propaganda and other hybrid warfare tools used should not be treated as a threat, as it only serves Russian interests. It should be approached as a challenge, while challenge as such can bring about threats or opportunities. If properly managed, some of the challenges Russia is bringing about to NATO and the EU can be skillfully turned into opportunities. The West just needs to learn not to underestimate Russia and keep intelligence as well as analytical bodies on stand-by so that they can provide in-depth research of Russian identity, culture and strategy. That would allow NATO and individual states to be better prepared for Russian actions. Challenges are always a driver for development and progress, as they should force pro-active approach and creativity.

The novelty of Russian warfare is primarily the use of means other than conventional. This applies mainly to long-term and well targeted policy, based on a precise strategy of building international links (networks) and the use of specific information warfare and propaganda. The analysis of Russian undertakings in Ukraine shows that the strategy of the "New Generation War" has been further developed and applied with the presumption it would reach specific targets. It managed to destabilize the country, divide the West, awakened fear in neighboring countries (mainly in the Baltic states and Poland as well as in Moldova and Georgia). It has also led to partition of Ukraine: ideological (with respect to the society) and physical (with respect to the territory). The annexation of Crimea has in turn become a fact the international community has long forgotten about and for which Russia has received a silent permission.

There is no doubt that the crisis in Ukraine has changed the relationship between NATO or the EU countries and Russia. It has certainly revived discussions on the need for the NATO's existence as well as its priority areas of operation and strategic planning. It forced the decision makers to wonder about defense capabilities and the ability to provide real support to particular countries in the event of an armed attack (Monaghan, 2014). Finally, there is also a need to introduce changes in the strategic communications which failed in countering Russian information propaganda.

Nowadays, the Russian Federation is not a direct threat to NATO or the EU countries, but it is getting to be more and more assertive, which should not be underestimated. The Russian Federation would rather not risk military confrontation with NATO at this stage, but will continue actions directed at its 
weakening and dissolution. Different approach to the situation and relations with Russia even among the countries of the Central-Eastern Europe region, not to even mention the whole NATO and inability to take solidarity actions, plays in favor of Russian strategy. Thus, the greatest challenge in this area will be to prevent Russia from undertaking actions directed at NATO fragmentation (or at least escalation of further divisions impeding common NATO activities). It is especially important for the Baltic states which feel threatened by Russian aggressive politics. This is an evidence for a clear change of strategy into asymmetric and hybrid warfare to which NATO is not fully prepared to answer to.

Russia counts on divisions within the EU and NATO which would work in its favor. NATO's strength and credibility relies on its unity, solidarity and ability to guarantee security of all its member states. If Russian methods are applied again, this time in the Baltic states, NATO will need to react. Therefore, new strategies need to be employed in order to be ready to prevent and counter Russian various hybrid war instruments. The greatest problem is that Russia is unlikely to use overt aggressive tools towards any of the NATO member states, but will try to destabilize some of them using non-military means. The impulse to unite and act should be internal (motivation) not external (negative motivating), it has to be pro-active (if NATO wants to maintain a specific global leadership with respect to security) not reactive. Therefore, claiming that NATO is grateful to Putin for re-uniting exposes its weakness.

\section{REFERENCES:}

Darczewska, J. (2014). The Anatomy of Russian Information Warfare: The Crimean Operation, a Case Study. Warsaw: Centre for Eastern Studies.

Karber, Ph. (2015). "Lessons Learned" from the Russo-Ukrainian War. Washington: ARCIC.

Lange-Ionatamišvili, E., Potjomkina, D. (2014). Combatting Russian Propaganda. Retrieved from: http://visegradinsight.eu/recommendations-for-combattingrussian-propaganda10122014.

Monaghan, A. (2014). Ukrainian Crisis and NATO-Russia Relations. Retrieved from: http://www.nato.int/docu/review/2014/Russia-Ukraine-Nato-crisis/Ukrainecrisis-NATO-Russia-relations/EN/index.htm.

Pomerantsev, P. (2014). Russia and the Menace of Unreality. Retrieved from: http:// www.theatlantic.com/international/archive/2014/09/russia-putin-revolutionizinginformation-warfare/379880. 
Prus, J. (2015). Russia’s Use of History as a Political Weapon. PISM Policy Paper, 12. Warsaw: Polish Institute of International Affairs.

Prus, J., Secrieru, S. (2015). Nastroje antyzachodnie w Rosji. Biuletyn PISM, 35. Warsaw: Polish Institute of International Affairs.

Shevtsova, L. (2007). Russia: Lost in Transition. The Yeltsin and Putin Legacies. Washington: Carnegie Endowment for International Peace.

Toffler, A., Toffler, H. (1994). War and Anti-War. Survival at the Dawn of the 21 st Century. London: Warner Books.

Van Herpen, M.H. (2015). Putin's Wars. The Rise of Russia's New Imperialism. London: Rowman \& Littlefield. 